\begin{tabular}{|c|c|c|c|}
\hline & НАУЧНО-ТЕХНИЧЕСКИЙ ВЕСТНИ & РМАЦИОННЫХ ТЕХНОЛОГИЙ, МЕХАНИКИ И ОПТИКИ & \\
\hline 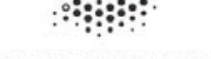 & $\begin{array}{lr}\text { март-апрель } 2016 & \text { Tом } 16 \text { № } 2 \\
\text { SCIENTIFIC AND TECHNICAL JOURN }\end{array}$ & $\begin{array}{l}\text { ISSN 2226-1494 } \\
\text { Ifttp://ntv.ifmo.rul } \\
\text { NFORMATION TECHNOLOGIES, MECHANICS AND OPTICS }\end{array}$ & 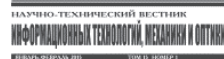 \\
\hline УНИВЕРСИТЕТ ИТМО & March-April $2016 \quad$ Vol. 16 No 2 & ISSN 2226-1494 $\quad$ http://ntv.ifmo.rulen & \\
\hline
\end{tabular}

\title{
DESIGNING FEATURES OF POWER OPTICAL UNITS FOR TECHNOLOGICAL EQUIPMENT
}

M.Ya. Afanasyev ${ }^{\text {a }}$, Yu.V. Fedosov ${ }^{\text {a,b }}$, A.A. Nemkova ${ }^{c}$

a ITMO University, Saint Petersburg, 197101, Russian Federation

bJSC “Russian Institute for Power Radiobuilding”, Saint Petersburg, 199048, Russian Federation

${ }^{\mathbf{c}}$ Chinese Academy of Sciences, Institute of Semiconductors, Beijing, 100083, China

Corresponding author: amax@niuitmo.ru

\section{Article info}

Received 26.01.16, accepted 14.02.16

doi:10.17586/2226-1494-2016-16-2-244-250

Article in English

For citation: Afanasyev M.Ya., Fedosov Yu.V., Nemkova A.A. Designing features of power optical units for technological equipment. Scientific and Technical Journal of Information Technologies, Mechanics and Optics, 2016, vol. 16, no. 2, pp. 244-250, doi:10.17586/22261494-2016-16-2-244-250

\section{Abstract}

This paper considers the question of an optical unit designing for transmitting power laser radiation through an optical fiber. The aim of this work is designing a simple construction unit with minimized reflection losses. The source of radiation in the optical unit described below is an ultraviolet laser with diode pumping. We present the general functioning scheme and designing features for the three main parts: laser beam deflecting system, laser beam dump and optical unit control system. The described laser beam deflection system is composed of a moving flat mirror and a spherical scattering mirror. Comparative analysis of the production technology for such mirrors was carried out, and, as a result, the decision was made to produce both mirrors of $99.99 \%$ pure molybdenum without coating. A moving mirror deflects laser emission from a source through a fiber or deflects it on a spherical mirror and into the laser beam dump, moreover, switching from one position to another occurs almost immediately. It is shown that a scattering mirror is necessary, otherwise, the absorbing surface of the beam dump is being worn out irregularly. The laser beam dump is an open conical cavity, in which the conical element with its spire turned to the emission source is placed. Special microgeometry of the internal surface of the beam dump is suggested for the better absorption effect. An optical unit control system consists of a laser beam deflection system, laser temperature sensor, deflection system solenoid temperature sensor, and deflection mirror position sensor. The signal processing algorithm for signals coming from the sensors to the controller is described. The optical unit will be used in special technological equipment.

\section{Keywords}

fiber optics, solid-state UV-laser, optical mirror, technological equipment, beam dump, surface microgeometry

\section{Acknowledgements}

We thank our colleagues, Nikita B. Margaryants and Galina E. Romanova, for assistance in carrying out experiments and computer modeling.

\section{УДК 658.512.26, 621.8-1/-9, 621.373.826}

\section{НЕКОТОРЫЕ ОСОБЕННОСТИ КОНСТРУИРОВАНИЯ СИЛОВЫХ ОПТИЧЕСКИХ БЛОКОВ ДЛЯ ТЕХНОЛОГИЧЕСКОГО ОБОРУДОВАНИЯ}

\section{М.Я. Афанасьев ${ }^{\text {a }, ~ Ю . В . ~ Ф е д о с о в ~}{ }^{\text {a,b }}$, А.А. Немкова}

${ }^{\mathbf{a}}$ Университет ИТМО, Санкт-Петербург, 197101, Российская Федерация

b ОАО «Российский институт мощного радиостроения», Санкт-Петербург, 199048, Российская Федерация

' Институт полупроводников Китайской Академии наук, Пекин, 100083, Китай

Адрес для переписки: amax@niuitmo.ru

Информация о статье

Поступила в редакцию 26.01.16, принята к печати 14.02 .16

doi:10.17586/2226-1494-2016-16-2-244-250

Язык статьи - английский

Ссылка для цитирования: Афанасьев М.Я., Федосов Ю.В., Немкова А.А. Некоторые особенности конструирования силовых оптических блоков для технологического оборудования // Научно-технический вестник информационных технологий, механики и оптики. 2016. Т. 16. № 2. С. 244-250. doi:10.17586/2226-1494-2016-16-2-244-250 


\begin{abstract}
Аннотация
Рассматриваются вопросы конструирования оптического блока для передачи силового лазерного излучения по оптическому волокну. Целью работы является разработка простого в изготовлении блока с минимизацией потерь на переотражения. Источником лазерного излучения в описываемом блоке служит ультрафиолетовый твердотельный лазер с диодной накачкой. Представлены общая функциональная схема блока и особенности проектирования трех основных модулей: системы отклонения лазерного луча, ловушки лазерного луча и системы контроля параметров лазерного блока. Описываемая система отклонения лазерного луча состоит из подвижного призматического зеркала и сферического рассеивающего зеркала. Проведен сравнительный анализ материалов и технологий изготовления подобных лазерных силовых зеркал, по результатам которого принято решение изготавливать оба зеркала из химически чистого молибдена без покрытия. Подвижное зеркало либо пропускает излучение от источника в волокно, либо отклоняет его на сферическое зеркало и в оптическую ловушку, причем переключение происходит практически мгновенно. Показано, что рассеивающее зеркало необходимо, так как в противном случае поглощающая поверхность оптической ловушки изнашивается неравномерно. Ловушка представляет собой открытый цилиндр с конической полостью, в которой располагается конический элемент, обращенный своим острием наружу в сторону подводимого излучения. Для улучшения эффекта поглощения предлагается специальная форма микрогеометрии всей внутренней поверхности ловушки. Система контроля параметров лазерного блока состоит из датчика наличия лазерного луча, датчика температуры лазера, датчика температуры электромагнита системы отклонения, датчика положения отклоняющего зеркала. Приведен алгоритм обработки сигналов с датчиков контроллером управления блока. Блок будет использован в составе специализированного технологического оборудования.
\end{abstract}

\title{
Ключевые слова
}

волоконная оптика, твердотельный лазер, оптическое зеркало, технологическое оборудование, оптическая ловушка, микрогеометрия поверхности

\section{Благодарности}

Авторы благодарят коллег - Никиту Борисовича Маргарянца и Галину Эдуардовну Романову за помощь в проведении экспериментов и компьютерном моделировании.

\section{Introduction}

Laser systems utilizing radiation of a few watts are spread widely at present. Such systems are used, for example, as part of different kinds of technological equipment, for instance, sheet cutting machines, engraving machines, marking machines, etc [1-3]. The power of lasers used in medicine and telecommunication equipment is increasing also. Special features of enlisted cases of power laser sources applications serve as a start-stop operation mode (there is radiation, or there is none), moreover, taking the beam on and taking it off, as a rule, must be performed immediately - and the operating result depends on it in many cases.

Such devices are based on a scheme similar as described in the works [4, 5]. For example, in [4, P. 390392], different laser beam deflecting systems are enumerated, formulas to calculate its deflection angle and trajectory are given, and different design types of systems implementing such principles are reviewed there. Similar devices are described in a number of patents too.

Current designs represent optical system integrated moving mirrors or semitransparent mirrors. The beam drives by turning the laser on and off. The optical elements redundancy leading to power losses and design complications are the main disadvantages of the mentioned schemes. The other typical feature is a simplified deflecting system, utilizing a flat mirror, deflecting the beam into the same beam dump area, which leads to its deterioration because of irregular wear of absorbing surface. In this paper the general design specifications of an optical unit with a simplified optical scheme, allowing increased dexterity in laser beam control with simplifying optical scheme are considered.

\section{Optical unit general functioning scheme}

The reviewed optical unit (fig. 1, a, b) consists of a laser beam source 2 placed on the same visual axis, a beam focusing part 12, comprising of two components - filter 13 and convergent lens 14 and terminating element 3 - optical fiber. The laser beam source is a solid-state ultraviolet (UV) laser with infrared diode pump and power supply unit, which controls input and serves as the laser beam source power control input.

Filter 13 is a transparent plate, made of blue-green glass type Schott BG60 (the closest Russian analogue is $\mathrm{C} 3 \mathrm{C} 22$ ) and intended to absorb emission of $580-700 \mathrm{~nm}$ wavelength, in which the laser pumping diode works. A convergent lens is intended to focus the laser beam on the terminating element - optical fiber. The laser beam deflecting system is placed between the laser beam source and the focusing parts. It comprises of two mirrors: flat mirror 1 of polygonal section and a spherical scattering mirror.

The flat mirror is mounted on two guidelines 5 using sleeve bearings 6 so it can move along one axis. The flat mirror drives through rod 9 by armature 8 and solenoid 7. Then returning to its initial position it is supplied by spring 10 . When the flat mirror is in the upper position, the beam firstly deflects from it, then deflects from spherical scattering mirror 11 , then it falls into the beam dump 4 . The optical unit is hermetically sealed and filled with nitrogen. The unit case is made of aluminum alloy and it forms an additional cooling supply for the laser beam source and solenoid. Fan cooling is also provided. Further design features of three main parts of optical unit such as: laser beam deflection system, laser beam dump and laser unit control system will be described. 

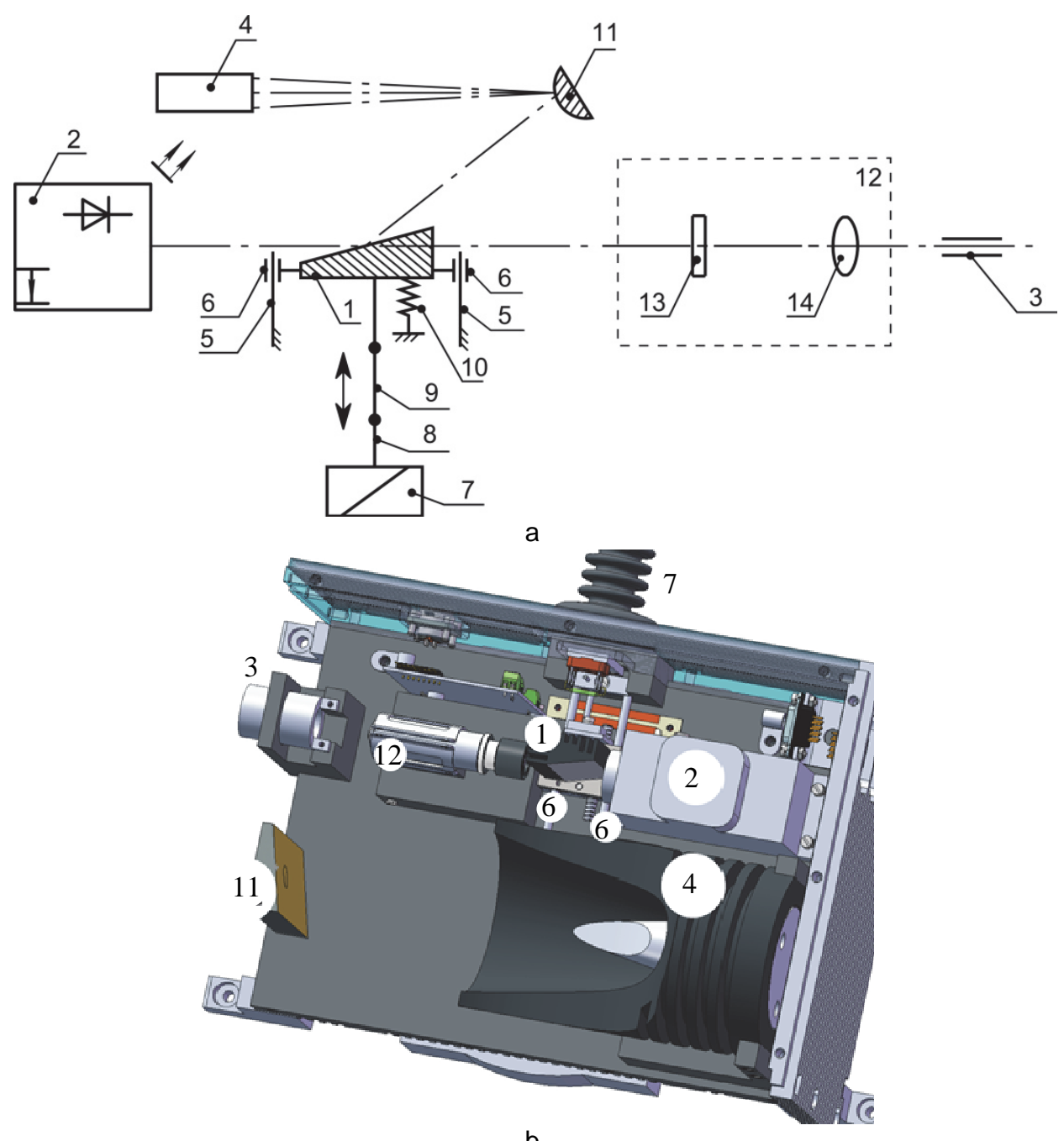

b

Fig. 1. Optical unit: general functioning scheme (a); 3d model (b).

1 - flat mirror; 2 - laser; 3 - optical fiber; 4 - beam dump; 5 - guideline; 6 - sleeve bearing; 7 - solenoid;

8 - armature; 9 - rod; 10 - spring; 11 - spherical scattering mirror; 12 - beam focusing part; 13 - filter; 14 - convergent lens

\section{Laser beam deflection system}

The general purpose of laser beam deflection system is to turn immediately the laser emission on and off, which is not possible by switching the laser power on and off. The laser module LSR445NL-1W was used. The main characteristics of the module are as follows:

- Peak emission wavelength is $450 \mathrm{~nm}$;

- Optical output power at $I=1.2 \mathrm{~A}$ is $1 \mathrm{~W}$;

- Beam divergence $\left(\theta_{\|}\right)$is 7 deg;

- Beam divergence $\left(\theta_{\perp}\right)$ is 23 deg.

Experimentally, it was proved that the laser module reaches nominal power only $90 \mathrm{~s}$ after switching the power on, when solenoid response time is not more than $0.001 \mathrm{~s}$. As stated earlier, the laser beam deflection system comprises of two mirrors: flat mirror of polygonal section and spherical scattering mirror. Three options of mirrors design were overviewed:

1. Aluminum mirrors.

2. Mirrors made of Chromium copper with gold coating.

3. Molybdenum mirrors.

The first option is the cheapest, and it is very easy to produce, however, it should be noted that aluminum (aluminum-coated) mirrors without any extra coating can be used only in the laboratory environment. For industrial use they should be protected with layer of some transparent substance, for instance, sulfur zinc, silicon monoxide, etc [6, 7]. On the other hand, aluminum mirrors are subject to mechanical wearing. It is very easy to 
scratch them during cleaning. Furthermore, aluminum has an coefficient of thermal expansion high enough $\left(22.2 \times 10^{-6} 1 / \mathrm{K}[8]\right)$ to lead to its deformation during continuous mirror heating by the laser beam.

The gold-coated mirrors made of chromium copper of grades C18200 (Russian analogues are БpX0.8 and БpX1) are the best today, especially during long beam influence $[9,10]$. These mirrors are able to provide high reflectance while being heat and corrosion resistent enough [11]. The Chromium copper coefficient of thermal expansion is less than aluminum and counts $17 \times 10^{-6} 1 / \mathrm{K}$ [12]. Nevertheless, using it in the given optical unit chromium copper mirrors is not sensible for the following reasons. First, gold coating, like aluminum, is not very strong, that makes it useless in the case when the mirror is subject to physical impact. Secondly, chromium copper is not easy to machine because of its low ductility. As a result, when producing mirrors of the given material, it is necessary to use complicated and costly technologies such as micromilling with diamond mills [9].

Molybdenum is the most durable and long lasting material for producing mirrors for reflecting power laser beams. The molybdenum mirrors may be used for industrial purposes while being exploited in the dusty conditions. This metal has an acceptable reflectance, low coefficient of thermal expansion $\left(5 \times 10^{-6} 1 / \mathrm{K}[8]\right)$ and substantial hardness (125 HB). The reflectance factor of a polished molybdenum surface of the wavelength of $500 \mathrm{~nm}$ allows molybdenum mirrors to be used without coating, or with coating to raise reflectance more. Molybdenum mirrors without additional reflective coating are durable and withstand rough cleaning more than mirrors with silver, aluminum coating, or protective coating. Only high material cost can be stressed. So, according to our analysis we can conclude that the most suitable material for deflecting system mirrors is pure monocrystalline molybdenum. It should be noted, that during material and technologal analysis for fabricating mirrors for power laser beams, a multilayer interference coatings were not considered because their properties are redundant for the given optical unit and complication of this technology will increase the unit cost [13-16].

The general part of the beam deflecting system is a flat mirror, linearly moving along guidelines using sleeve bearings, drives by h-armature, and a control input of which forms control input of laser beam deflecting system. At first, the laser beam deflecting system design utilized mirror rotating mechanism with lever actuation, but during analysis this design has been considered ineffective. The scattering mirror is used for laser beam attenuation and for continuous beam dump exposure. As a result, the beam dump heats regularly and absorbs beam energy more effectively.

The scattering mirror design (fig. 2) comprises of the main part 1, which is needed for the mounting mirror inside the optical unit and cylindrical inserts 2, which are placed into holes drilled in the main part. The parts are soldered together. According to the results of experiments, the most suitable technology is soldering with Au-Ni-Pd solder in a deep vacuum using quick heating. When heating in the atmosphere, molybdenum oxidizes quickly, forming annealing colors (discoloration), changing the mirror optical properties. At present, additional research is being carried out to develop the technology of electrochemical darkening of the molybdenum mirrors non-reflecting surfaces. Darkening is necessary for absorbing spurious emissions appearing due to partial beam reflection from parts of focusing system and optical fiber face end.

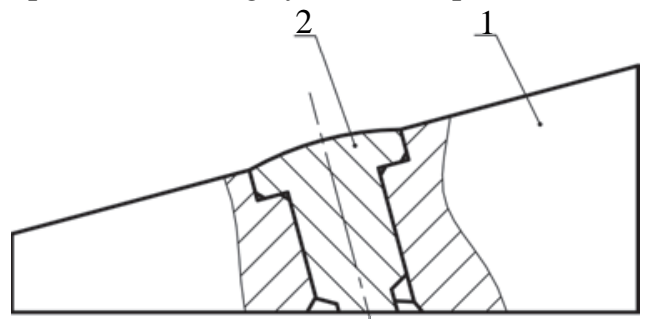

Fig. 2. Scattering mirror design: 1 - mounting part; 2 - cylindrical inserts

\section{Laser beam dump}

The laser beam dump is a part for absorbing emission of the UV-band. The laser beam dump (fig. 3) represents a cylindrical case with an open conical cavity, narrowing to its deep end, to which conical part 2 with its spire turned outside the conical cavity to emission source is mounted.

Case 1 and conical part 2 are turning parts with the same center line. The conical part 2 is mounted in case 1 using screws 3 . Case 1 conical cavity surface 4 and the surface 5 of the conical part 2 have regular dimples forming continuous grooving. Moreover, the dimples profile turned to conical part 2 face has a configuration, which sets multiple reflections of the supplied laser beam at angles that definitely exclude incoming beam reflection back from beam dump. Conical part 2 and case 1 are connected by cylindrical surfaces 6, making them coaxial. The case 1 is made of aluminum alloy grade ISO 2024 AlCu4Mg1(Russian analogue is Д16), which has high coefficient of thermal conductivity $(130 \mathrm{~W} /(\mathrm{m} \cdot \mathrm{K}))$ [17], while the conical part is made of Titanium grade 2 (Russian analogue is BT1-0), which has low coefficient of thermal conductivity $(8.6 \mathrm{~W} /(\mathrm{m} \cdot \mathrm{K}))$ [8]. This excludes structural deformations due to heat expansion of conical part 2. For improving the thermal conductivity on connected surfaces of case 1 and conical part 2 thermal grease Arctic Silver 5 (the closest Russian analogue is КПТ-8) is deposited. Passive cooling is performed by heat emission from the case 1 
outer surface. On the case 1 outer surface, recesses were made, which are working as a passive cooler. In this case, the laser beam dump dimensions allow use without any additional air or water cooling simplifying optical unit design significantly.

For improving laser beam absorbtion, surface 4 of case 1 conical cavity and surface 5 of conical part 2 are coated with ammonium molybdate, which phototermal selective properties are studied in [18]. The unit functions in the following way. UV-emissions fall on case 1 conical cavity surface 4 and on conical part 2 surface 5 . Regardless of the angle all reflections are excluded (fig. 4).

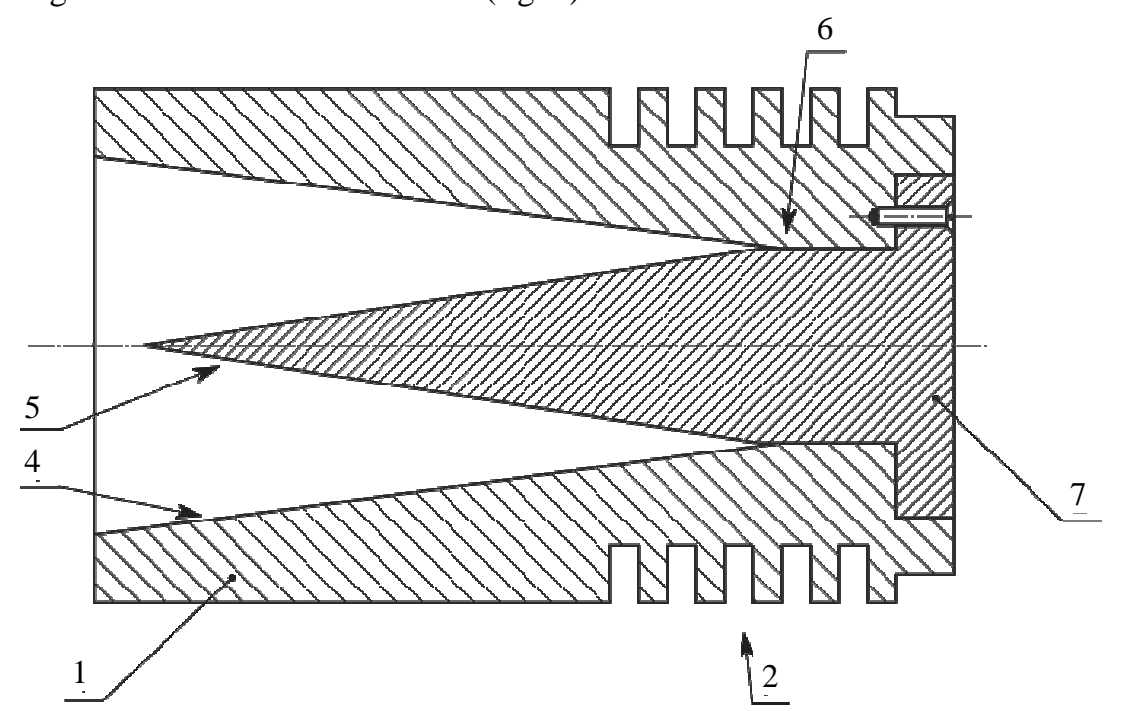

Fig. 3. Optical dump: 1 - case; 2 - conical part; 3 - screws; 4, 5 - conical cavity surfaces; 6 - cylindrical surfaces; 7 - recesses

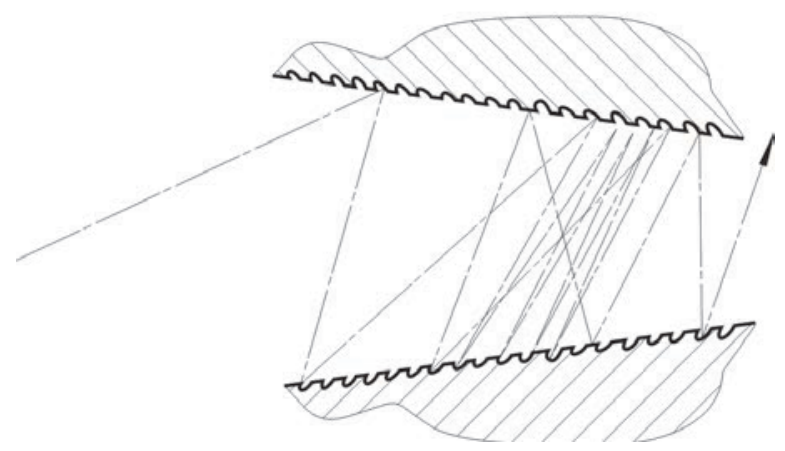

Fig. 4. Microgeometry of the surface

Multiple partial absorbing and reflection of emission into case 1 (fig. 3) conical cavity occurs due to surfaces 4 and 5 having dimples and being coated with ammonium molybdate, As a result, beam energy turns into heat which is emitted into the external environment from the case 1 outer surface. Importantly, the ammonium molybdate coating eliminates the possibility of the appearance of spurious emissions and recesses 7 (fig. 3) improves cooling efficiency.

\section{Optical unit control system}

The optical unit control system consists of a controller and sensors. The following sensors are mounted in the unit:

1. Laser beam sensor;

2. Laser temperature sensor;

3. Solenoid temperature sensor;

4. Deflecting mirror position sensor.

The design analysis showed that during the operation two types of malfunctions may occur: the unit components overheating and laser module failure (absence of beam on the fiber face). The main heat sources in the unit are the laser module and solenoid.

A separate temperature sensor for each of them is intended. Both temperature sensors consist of thermoresistors, which are connected with a signal normalization scheme built on a comparator. The maximum 
response temperature is set with the adjusting resistor (evaluates experimentally), when reaching its high logical level (logical " 1 ") on the unit's output is set.

The controller polls the sensors over by timer interrupt once per second. If during five seconds the logical level remains high, the controller gradually increases cooler rotation speed until it reaches maximum and waits for thirty seconds more. If the logical level remains high, the controller switches the power off, warns about the failure, and makes an appropriate record in the error log. Emission on the unit's output may be absent when the laser module is malfunctioned, or when the laser beam deflection system has malfunctioned, which occurs due to mechanism jam, or solenoid failure (or solenoid control module failure). Laser module failure cannot be determined usually, because it is mounted in the hermetically sealed case, so sensor design which checks emission presence without interrupting unit's operation was required. Therefore, a sensor solar array cell (photosensor) with dimensions of $30 \times 30 \mathrm{~mm}$ was used. The sensor is mounted so, when switching the laser unit on, it is exposed enough to produce a voltage of about $1.2 \mathrm{~V}$. The given voltage is enough to turn on the fieldeffect transistor (transistor IRLZ44 is used), which is driven by a logical level and forms a high logical level, which is transferred to the input of microcontroller.

The second reason of emission absence is complex and includes mirror moving mechanism jam, rod break, changing the spring rigidity caused by metal fatigue, spring jam, solenoid failure or solenoid control unit failure. It is easy to note that all of this is caused by the wrong position of the deflecting mirror. The operative deflective mirror at any time must be in one of two positions: in one of them laser beam must be freely going into focusing system, in the second - it deflects from the spherical scattering mirror and falls into the beam dump.

Therefore, sensor checking one of mirror's positions is necessary. The sensor must be robust and simple. In the unit, a touchless magnetic sensor - balanced magnetic switch is used. The laser beam control algorithm consists of: the controller, according to the timer, interrupt polls the photosensor once per second. The high logical level on photodetector output means the laser module is operating properly. In the future it is planned to scan the voltage on photodetector output directly. As the used laser module is based on solid-state laser, it means a slow decreasing of power, caused by deterioration of diode pump semiconductor.

In this case, voltage from photosensor will be transferred to controller analog-to-digital converter for rough evaluation of the power of the laser beam. It is obvious that the correlation between this voltage and beam intensity will be close to linear, and it will help to determine the time of laser diode replacement. The deflecting beam mirror position is determined by Boolean value. The logical "1" means passing the beam through the fiber, and " 0 " means deflecting the beam into the beam dump. The magnetic sensor works in the same way. Consequently, if the photosensor is exposed by the laser beam, the deflecting system is working as follows: the controller performs "exclusive or" operation between the value, indicating position, and the value received from the sensor. If the result is logical "0", the deflecting system is working properly. Otherwise the controller switches the laser unit off. A controller fan failure is also possible.

At this time a stand-alone sensor which examines fan workability is not provided. This is due to the massive aluminium unit case is a good cooling supply for using laser module of $1 \mathrm{~W}$ power. In case of replacing the current laser module with more power and the necessity of active cooling, only the optical unit software editing will be necessary. At this moment for optical cooling an ordinary cooling fan with delivery volume of 1 cubic meter per minute with analog rate indicator is used. The rate indicator output can be connected with controller's analog-to-digital converter, which can calculate the true fan rotation rate. Currently, for the sake of saving controller resources, the rate indicator output is still unengaged.

\section{Conclusion}

In this article the design features of an optical unit, which translates power UV-emission through optical fiber have been indicated. The optomechanical laser beam deflecting system consisting of moving flat mirror and scattering spherical mirror is reviewed. Mirrors' material choice, ensuring needed optical characteristics and simplicity of optical system manufactory and serving was stated. Laser beam dump with passive cooling was described.

The possibility of improving emission absorbing parameters by beam dump surfaces microgeometry changing was shown. At present the optical unit is using for determinating parameters of experimental optical fibers. Further unit will be used as a part of technological equipment.

\section{References}

1. Tsoukantas G., Salonitis K., Stournaras A., Stavropoulos P., Chryssolouris G. On optical design limitations of generalized two-mirror remote beam delivery laser systems: the case of remote welding // International Journal of Advanced Manufacturing Technology. 2007. V. 32. N 9-10. P. 932-941. doi: 10.1007/s00170-0050400-7

2. Ussing T., Petersen L.V., Nielsen C.B., Helbo B., Hojslet, L. Micro laser welding of polymer microstructures using low power laser diodes // International Journal of Advanced Manufacturing Technology. 2007. V. 33. N 1-2. P. 198-205. doi: 10.1007/s00170-007-0969-0 
3. Kuhn A., Blewett I.J., Hand D.P., French P., Richmond M., Jones J.D.C. Optical fiber beam delivery of highenergy laser pulses: beam quality preservation and fiber end-preparation // Optics and Lasers in Engineering. 2000. V. 34. N 4-6. P. 273-288. doi: 10.1016/S0143-8166(00)00082-8

4. Вычислительная оптика. Справочник / Под ред. М. М. Русинова, А.П. Грамматина, П.Д. Иванова и др. Л.: Машиностроение, 1984. 423 с.

5. Запрягаева Л.А., Свешникова И.С. Расчет и проектирование оптических систем. Учебник для вузов. М.: Логос, 2000. 584 с.

6. Ройх И.Л. Нанесение защитных покрытий в вакууме. Покрытия [Электронный ресурс]. Режим доступа: http://de.ifmo.ru/bk_netra/page.php?tutindex=46\&index=28\&layer=1, свободный, Яз. рус. (дата обращения 10.02.2016).

7. Galyautdinov R.T., Kashapov N.F., Luchkin G.S. Formation of protective coatings for aluminium mirrors by magnetron sputtering // Welding International. 2003. V. 17. N 8. P. 655-658. doi: 10.1533/wint.2003.3184

8. Температурный коэффициент линейного расширения [Электронный ресурс]. Режим доступа: http://temperatures.ru/pages/temperaturnyi_koefficient_lineinogo_rasshireniya, свободный, Яз. рус. (дата обращения 15.02.2016).

9. Солк С.В. Разработка и исследование технологических методов изготовления, контроля и юстировки оптических элементов и устройств инфракрасных приборов: дис. ... докт. техн. наук. СанктПетербург, Университет ИТМО, 2015. 287 с.

10. Наумов М.Б. Лазерные силовые зеркала. М.: МИРЭА, 2008. 171 с.

11. Лахтин Ю.М., Леонтьева В.П. Материаловедение: Учебник для высших технических учебных заведений. 3-е изд. М.: Машиностроение, 1990. 528 с.

12.Характеристики материала БрХ. Марочник стали и сплавов [Электронный ресурс]. Режим доступа: http://www.splav-kharkov.com/mat_start.php?name_id=1189, свободный, Яз. рус. (дата обращения 16.02.2016).

13. Yoshida K., Takeuchi K., Kato Y., Fujiwara E., Yamashita K., Kurosawa K., Sasaki W., Okamoto H. Superpolished single crystal molybdenum mirror for x-ray ultraviolet to $\mathrm{x}$-ray radiation // Applied Physics. 1988. V. 52. N 14. P. 1111-1113. doi: $10.1063 / 1.99177$

14.Leontyev A., Semerok A., Farcage D., Thro P.-Y., Grisolia C., Widdowson A., Coad P., Rubel M. Theoretical and experimental studies on molybdenum and stainless steel mirrors cleaning by high repetition rate laser beam // Fusion Engineering and Design. 2011. V. 86. N 9-11. P. 1728-1731. doi: 10.1016/j.fusengdes.2010.12.068

15. Sherwood B.J. Molybdenum laser mirrors // Metal Finishing. 2008. V. 106. N 4. P. 87-88.

16. Mizusawa M., Sakurai K. Specular and non-specular X-ray reflection from a single-crystal molybdenum mirror surface // Nuclear Instruments and Methods in Physics Research Section B: Beam Interactions with Materials and Atoms. 2003. V. 199. P. 139-142. doi: 10.1016/S0168-583Х(02)01621-X

17.Алюминий Д16 дуралюмин Д16, дюраль Д16 [Электронный ресурс]. Режим доступа: http://metallicheckiy-portal.ru/marki_metallov/alu/D16, свободный, Яз. рус. (дата обращения 14.02.2016).

18. Gonzalez F., Barrera E.C., Rosas R.C. Photothermal selective coatings of black molybdenum // Revista Mexicana de Ingeniera Qumica. 2010. V. 9. N 1. P. 79-83.

Maxim Ya. Afanasyev

Yuri V. Fedosov

Anastasia A. Nemkova

Афанасьев Максим Яковлевич

Федосов Юрий Валерьевич

Немкова Анастасия Александровна
PhD, Associate professor, ITMO University, Saint Petersburg, 197101, Russian Federation, amax@niuitmo.ru

$\mathrm{PhD}$, Associate professor, ITMO University, Saint Petersburg, 197101, Russian Federation; engineer, JSC "Russian Institute for Power Radiobuilding”, Saint Petersburg, 199048, Russian Federation, yf01@yandex.ru

- $\quad \mathrm{PhD}$, Associate professor, Associate professor, Chinese Academy of Sciences, Institute of Semiconductors, Beijing, 100083, China, anastasia.nemkova@yahoo.com

- кандидат технических наук, доцент, Университет ИТМО, СанктПетербург, 197101, Российская Федерация, amax@niuitmo.ru

- кандидат технических наук, доцент, Университет ИТМО, СанктПетербург, 197101, Российская Федерация; инженер, ОАО «Российский институт мощного радиостроения», Санкт-Петербург, 199048, Российская Федерация, уf01@yandex.ru

кандидат технических наук, доцент, доцент, Институт полупроводников Китайской Академии наук, Пекин, 100083, Китай, anastasia.nemkova@yahoo.com 